\title{
KONTRIBUSI USAHA MIKRO KECIL DAN MENENGAH TERHADAP TINGKAT PERTUMBUHAN PENDAPATAN DAERAH PROVINSI DKI JAKARTA
}

\author{
Prasetio Ariwibowo \\ Dwi Rorin Mauludin Insana \\ Universitas Indraprasta PGRI Jakarta \\ e-mail: Prasetio.ariwibowo@yahoo.com
}

\begin{abstract}
This study aims to analyze the potential and contribution of retribution revenue from the City Administration Government of Central Jakarta, East Jakarta, and South Jakarta to the total $D K I$ Jakarta Original Regional Revenue (PAD). This study uses primary data and secondary data. Qualitative descriptive analysis method focused on the development strategy of MSME business empowerment in the form of retribution income performance based on purposive sampling and literature study with Growth analysis testing tools and Share analysis. Growth rate (Growth) Temporary Location retribution income (LokSem) and Patronage Locations (LokBin) in the city government The administration of South Jakarta, Central Jakarta, and East Jakarta has fluctuated every month. Total revenue retribution (Loksem and Lokbin) Administrative City Administration of South Jakarta, Central Jakarta, and East Jakarta does not have a large influence on the total Regional Original Revenue (PAD) of DKI Jakarta Province in 2016.In order to improve the performance of retribution, it can be concluded that the strategy in the form of a Performance SOP and Performance Accountability Report (LPJK) in each month has an integrated Management Information System for all SME \& Trade Sub-Centers in DKI Jakarta, analyzing $5 \mathrm{C}$ (Capital, Collateral, Character, Capacity, and Condition) and 7 P (Personality, Party, Purpose, Prospect, Payment, Profitability, and Protection).
\end{abstract}

Keywords: growth share, retribution, local original income, location guided, temporary location

\begin{abstract}
ABSTRAK
Penelitian ini bertujuan untuk menganalisis potensi dan kontribusi pendapatan retribusi dari Pemerintah Kota Administrasi Jakarta Pusat, Jakarta Timur, dan Jakarta Selatan terhadap total Pendapatan Asli Daerah (PAD) DKI Jakarta. Penelitian ini menggunakan data primer dan data sekunder. Metode analisis deskriptif kualitatif yang difokuskan pada strategi pengembangan pemberdayaan usaha UMKM dalam bentuk kinerja pendapatan retribusi yang berdasarkan purposive sampling dan studi kepustakaan dengan alat uji analisis Growth dan analisis Share. Tingkat pertumbuhan (Growth) pendapatan retribusi Lokasi Sementara (LokSem) dan Lokasi Binaan (LokBin) di Pemerintah kota Administrasi Jakarta Selatan, Jakarta Pusat, dan Jakarta Timur mengalami fluktuatif tiap bulannya. Total pendapatan retribusi (Loksem dan Lokbin) Pemerintah Kota Administrasi Jakarta Selatan, Jakarta Pusat, dan Jakarta Timur tidak memiliki pengaruh yang besar terhadap total Pendapatan Asli Daerah (PAD) Provinsi DKI Jakarta di Tahun 2016. Guna meningkatkan kinerja retribusi, dapat disimpulkan strategi berupa Terdapat SOP Kinerja dan Laporan
\end{abstract}


Pertanggung Jawaban Kinerja (LPJK) di tiap bulannya, memiliki Sistem Informasi Manajemen terpadu bagi seluruh Sudin UKM \& Perdagangan di DKI Jakarta, melakukan analisa 5 C (Capital, Collateral, Character, Capacity, and Condition) dan 7 P (Personality, Party, Purpose, Prospect, Payment, Profitabillity, and Protection).

Kata kunci: growth share, Lokasi Sementara (LokSem), Lokasi Binaan (LokBin), retribusi, pendapatan asli daerah.

Usaha Kecil Menengah di DKI Jakarta mempunyai cakupan yang luas meliputi seluruh sektor kegiatan ekonomi, sementara yang lazim kita jumpai di kota maupun provinsi lainnya di Indonesia sektor industri kecil memiliki peluang usaha yang cukup besar. DKI Jakarta, persentase peranan pengusaha usaha kecil bernilai lebih rendah dibandingkan industri besar dalam pertumbuhan ekonomi di DKI Jakarta.

Menurut Undang-Undang Nomor 20 Tahun 2008 tentang Usaha Mikro, Kecil dan Menengah (UMKM), usaha mikro adalah usaha produktif milik orang perorangan dan/atau badan usaha perorangan yang memenuhi kriteria usaha mikro sebagaimana diatur dalam Undang-Undang ini. Usaha kecil adalah usaha ekonomi produktif yang berdiri sendiri, yang dilakukan oleh orang perorangan atau badan usaha yang bukan merupakan anak perusahaan atau bukan cabang perusahaan yang dimiliki, dikuasai, atau menjadi bagian baik langsung maupun tidak langsung dari usaha menengah atau usaha besar yang memenuhi kriteria usaha kecil sebagaimana dimaksud dalam undang-undang ini. Usaha menengah adalah usaha ekonomi produktif yang berdiri sendiri, yang dilakukan oleh orang perseorangan atau badan usaha yang bukan merupakan anak perusahaan atau cabang perusahaan yang dimiliki, dikuasai, atau menjadi bagian baik langsung maupun tidak langsung dengan usaha kecil atau usaha besar dengan jumlah kekayaan bersih atau hasil penjualan tahunan sebagaimana diatur dalam undang-undang ini.

Menurut Tambunan (2009:51), sektor UMKM meliputi berbagai sektor bisnis, seperti pertanian, pertambangan dan penggalian, industri manufaktur, listrik, gas dan air bersih, bangunan, perdagangan, hotel dan restoran, transportasi dan telekomunikasi, keuangan, penyewaan dan jasa, serta jasa-jasa lainnya. Sektor industri terbagi lagi menjadi beberapa bagian yakni makanan, minuman, dan tembakau, tekstil, pakaian jadi kulit dan alas kaki, kayu dan produk-produk kayu, kertas percetakan dan publikasi, serta kimia (termasuk pupuk). Adapula produk-produk dari karet, semen dan produk mineral non logam, produk-produk dari besi dan baja, alat-alat transportasi, mesin dan peralatannya, serta olahan lainnya.

Pengertian strategi menurut Hamel dan Prahalad (2011) adalah tindakan yang bersifat incremental (senantiasa meningkat) dan terus-menerus, serta dilakukan berdasarkan sudut pandang tentang apa yang diharapkan oleh para pelanggan di masa depan. Dengan demikian, strategi hampir dimulai dari apa yang terjadi dan bukan dimulai dari apa yang terjadi. Terjadinya kecepatan inovasi pasar yang baru dan perubahan pola konsumen memerlukan kompetensi inti (core competencies). Perusahaan perlu mencari kompetensi inti di dalam bisnis yang dilakukan. Sedangkan menurut De Kluyver \& Pearce (2006), begitu banyak pengertian manajemen strategi, namun pada dasarnya manajemen strategi merupakan suatu sistem yang sebagai satu kesatuan memiliki berbagai komponen yang saling berhubungan dan mempengaruhi. Komponen pertama adalah perencanaan strategi dengan unsur-unsurnya yang terdiri dari visi, misi, tujuan dan strategi utama organisasi. Sementara itu komponen kedua adalah perencanaan operasional dengan unsur- 
unsurnya, sasaran dan tujuan operasional, pelaksanaan fungsi-fungsi manajemen berupa fungsi pengorganisasian, fungsi pelaksanaan dan fungsi penganggaran, kebijaksanaan situsional, jaringan kerja internal dan eksternal, fungsi kontrol dan evaluasi serta umpan balik.

Formulasi strategi melibatkan penetapan serangkaian tindakan yang tepat guna mencapai tujuan perusahaan. Formulasi strategi meliputi pengembangan misi bisnis, analisis SWOT yang mengidentifikasi peluang dan ancaman eksternal serta mengukur dan menetapkan kelemahan dan kekuatan internal dan menetapkan tujuan jangka panjang. Proses formulasi strategi dilakukan dalam tiga tahapan berupa pertanyaan, yaitu:

1. Where are we now ?

Pada tahap ini, didentifikasi kondisi bisnis dan perusahaan saat ini, diawali dengan isu-isu mendasar seperti visi dan misi perusahaan, dan siapa pemegang saham utama. Selanjutnya adalah evaluasi detail mengenai kinerja perusahaan saat ini, kondisi lingkungan makro (sosial politik, ekonomi, hukum, dan teknologi) dimana perusahaan beroperasi, peluang dan ancaman di lingkungan industri, dan kekuatan dan kelemahan internal.

2. Where do we go ?

Dari jawaban tahap pertama, akan ditelusuri alternatif-alternatif strategi yang ada. Contoh strategi alternatif pada level unit bisnis adalah pilihan seperti apakah akan berkonsentrasi pada pertumbuhan di beberapa segmen pasar atau fokus di pasar yang lebih luas, apakah akan bekerja sama (partner) dengan perusahaan lain atau tidak, apakah akan fokus pada nilai tambah atau solusi low-cost untuk konsumen. Pada level korporat, prosesnya terfokus pada pembentukan portofolio bisnis dan pada pembuatan penyesuaian filosofi dan proses. Pada kedua level tersebut (unit bisnis dan korporat), hasil yang diharapkan adalah sebuah pernyataan strategi yang sebenarnya (the stated strategic intent) yang dapat mengidentifikasi panduan konsep bisnis perusahaan atau faktor yang dapat mempengaruhi perusahaan ke depannya.

3. How do we get there ?

Fokus dari pertanyaan ini adalah bagaimana cara mencapai tujuan yang diinginkan. Isu paling penting pada tahap ini adalah bagaimana menjembatani perbedaan kemampuan (capability gap) antara kemampuan perusahaan saat ini dan kemampuan yang dibutuhkan untuk mencapai pernyataan strategi yang sebenarnya (stated strategic intent).

Selain pajak daerah, sumber pendapatan asli daerah yang cukup besar peranannya dalam menyumbang pada terbentuknya pendapatan asli daerah adalah retribusi daerah. Menurut Lutfi (2006), retribusi daerah merupakan semacam mekanisme pasar dalam sektor publik, dimana terjadi suatu transaksi antara pemerintah dengan warga masyarakat memiliki kaitan erat antara sejumlah uang yang dibayarkan dengan manfaat yang diterima. Menurut Wirawati et,al (2013), Retribusi daerah dapat digolongkan menjadi tiga golongan yakni retribusi jasa umum yang terdiri dari retribusi pelayanan kesehatan, retribusi pelayanan kebersihan, retribusi pergantian biaya cetak KTP dan akta catatan sipil, retribusi pelayanan parkir di jalan umum, dan retribusi pengujian kendaraan bermotor. Retribusi jenis usaha terdiri dari retribusi terminal dan retribusi rumah potong hewan, sedangkan retribusi perijinan tertentu terdiri dari retribusi izin mendirikan bangunan, retribusi izin keramaian, retribusi izin trayek, retribusi izin usaha perikanan, retribusi pemindahan kendaraan bermotor, dan retribusi izin pencari kerja. Menurut Hakim (2012), lain-lain penerimaan yang sah merupakan jenis penerimaan daerah yang terdiri dari: lain-lain penerimaan yang sah, penerimaan dari provinsi, penerimaan dari kabupaten/kota dan kekurangan tunjangan fungsional guru. 
Menurut Hakim (2012), fungsi keuangan negara atau daerah adalah sebagai berikut:

1. Fungsi Alokasi

Proses dimana sumber daya (resources) nasional dipergunakan untuk barang privat dan barang publik dimana keduanya sangat dibutuhkan oleh masyarakat.

2. Fungsi Retribusi

Peranan keuangan negara dalam hal ini anggaran dalam rangka pembagian kembali pendapatan, baik berdasarkan pemilikan sumber daya atau faktor-faktor produksi.

3. Fungsi Stabilitas

Anggaran negara merupakan alat kebijaksanan makro pemerintah. Bila pemerintah menaikkan pajak, maka konsumsi rumah tangga berkurang komponen pengeluaran agregat. Sebaliknya apabila pemerintah menurunkan pajak maka konsumsi rumah tangga akan lebih tinggi dan pengeluaran agrerat menjadi lebih besar yang pada gilirannya akan meningkatkan output (pendapatan nasional).

Sejak zaman penjajahan hingga saat ini, sejarah perkembangan perekonomian di Indonesia dapat kita bedakan menjadi perekonomian usaha negara, usaha swasta besar nasional, dan usaha swasta asing. Berdasarkan hasil penelitian yang dilakukan oleh Prasetyo dan Harjanti (2013), Pendapatan Domestik Regional Bruto (PDRB) Jawa Timur yang bertumbuh sebesar $7,27 \%$ pada tahun 2012. PDRB Jawa Timur sendiri mendapat sumbangan yang cukup besar dari sektor UMKM pada tahun 2011 sumbangan UMKM mencapai 54,34\% dari total PDRB dan nilainya mencapai Rp. 480,2 triliun dari total PDRB yang dihasilkan seluruh lapangan usaha, mengalami peningkatan dibanding 2010 dengan kontribusi 53,82\% atau sebesar Rp. 418,99 triliun. Pencapaian PDRB UMKM pada tahun 2011 lebih besar 0,52\% dibanding kontribusinya pada tahun 2010 (Badan Pusat Statistik Jawa Timur, 2010). Dalam kondisi yang demikian, menunjukkan bahwa UMKM merupakan sektor tulang punggung dalam meningkatkan taraf hidup masyarakat kelas menengah ke bawah dibandingkan dengan perananan industri-industri besar terhadap rasio perbandingan peranan sektor industri terhadap pembangunan ekonomi di Indonesia khususnya di DKI Jakarta.

Penelitian ini akan menganalisis lebih dalam strategi apa saja yang hendaknya dilakukan para pengusaha UMKM dan Pemerintah Daerah di DKI Jakarta mempertahankan dan meningkatkan jumlah pendapatan usaha dan usaha. Pemerintah DKI Jakarta menghadapi persaingan pasar bebas (MEA, AFTA, ACFTA, WTO, APEC, dll.) dan program pembangunan perekonomian baik industriindustri besar dalam negeri maupun luar negeri yang beroperasi di DKI Jakarta.

Tujuan dari penelitian ini adalah menganalisis kondisi perkembangan kontribusi berbagai sektor UMKM DKI Jakarta terhadap Pendapatan Daerah di Provinsi DKI Jakarta, menganalisis strategi mempertahankan dan meningkatkan kualitas pembangunan perekonomian di Provinsi DKI Jakarta khususnya di sektor UMKM di masa mendatang. Berdasarkan hasil penelitian sebelumnya, Wenny (2012), menujukkan bahwa Pendapatan Asli Daerah (PAD) secara simultan memiliki pengaruh terhadap kinerja keuangan, namun, secara parsial Pendapatan Asli Daerah yang sah yang dominan mempengaruhi kinerja keuangan, sedangkan pajak daerah, retribusi daerah, dan hasil perusahaan dan kekayaan daerah tidak dominan mempengaruhi kinerja keuangan pada pemerintah kabupaten dan kota di Provinsi Sumatera Selatan.

Devita dkk. (2014) menyatakan bahwa PAD (Pendapatan Asli Daerah) dan DAU (Dana Alokasi Umum) secara simultan dan parsial dapat meningkatkan belanja langsung dan belanja tidak langsung sementara jumlah penduduk mengurangi peningkatan belanja langsung. Hal ini berbeda dengan belanja tidak langsung yang memiliki efek positif karena pertumbuhan penduduk di 
kabupaten/kota di Jambi dapat meningkatkan alokasi belanja pegawai sedangkan untuk belanja langsung terutama untuk belanja modal tidak efisien. Selanjutnya pemerintah provinsi meningkatkan Dana Alokasi Umum (DAU) kepada Pemerintah kabupaten/kota di Jambi untuk meningkatkan retribusi masing-masing kabupaten/kotamadya di masa mendatang.

Penelitian ini dilakukan dalam lingkup manajemen strategik. Pengertian purposive sampling menurut Sugiyono dalam Mayasari dkk. (2014) adalah teknik pengambilan sampel sumber data dengan pertimbangan tertentu. Menurut Umar (2005:303), menyatakan bahwa objek penelitian menjelaskan tentang apa dan atau siapa yang menjadi objek penelitian, juga dimana dan kapan penelitian dilakukan, bisa juga hal-hal lain jika dianggap perlu.

\section{METODE PENELITIAN}

Penelitian ini menggunakan metode analisis deskriptif kualitatif yang difokuskan pada strategi pengembangan pemberdayaan usaha UMKM yang berdasarkan sampel purposif dan studi kepustakaan dari data statistik di Badan Pusat Statistik Republik Indonesia. Penelitian ini menggunakan data yang berasal dari Badan Pusat Statistik DKI Jakarta dan Suku Dinas UKM \& Perdagangan Kota Administrasi Jakarta Pusat, Jakarta Timur, dan Jakarta Selatan tahun 2010-2015 sebagai data primer dan sekunder objek análisis penelitian.

Lokasi penelitian di DKI Jakarta yang berdasarkan sampling purposive. Studi literatur diperoleh dari data statistik di Badan Pusat Statistik Republik Indonesia, Badan Pusat Statistik DKI Jakarta dan dan Suku Dinas UKM \& Perdagangan Kota Administrasi Jakarta Pusat, Jakarta Timur, dan Jakarta Selatan tahun 2010-2015. Alasan yang menjadi dasar pemilihan lokasi penelitian ini adalah provinsi DKI Jakarta telah mengalihkan Pajak Bumi dan Bangunan pedesaan dan perkotaan (PBB-P2) sebagai pajak daerah pada tahun 2012. Provinsi DKI Jakarta melaksanakan pengalihan PBB-P2. Hal ini dikarenakan provinsi DKI Jakarta merupakan instansi pemerintah yang berwenang dengan memiliki tugas pokok dan fungsinya dalam tata bidang perpajakan daerah di Provinsi DKI Jakarta.

Tingkat pertumbuhan retribusi tiap daerah di DKI Jakarta dari tahun ke tahun diukur menggunakan metode growthshare:

$$
\text { Growth }=[\mathrm{Tn}-(\mathrm{Tn}-1) / \mathrm{Tn}-1] \times 100 \%
$$

Untuk menganalisis kondisi pengaruh retribusi UMKM di tiap kota Administrasi Jakarta yang dijadikan sampel dalam penelitian ini terhadap kondisi ekonomi di DKI Jakarta menggunakan analisis Share/pangsa retribusi dengan metode perhitungan:

\section{Share $=[\mathrm{NP} 1 / \mathrm{NP} 2] \times 100 \%$}

\section{HASIL DAN PEMBAHASAN}

\section{Analisis Growth Pendapatan Retribusi}

Berdasarkan Tabel 1, dapat ketahui bahwa tingkat pertumbuhan pendapatan retribusi Lokasi Sementara (LokSem) di kota Administrasi Jakarta Selatan, Jakarta Pusat, dan Jakarta Timur mengalami naik turun. Hal ini dikarenakan berdasarkan info yang peroleh dari Kasudin UKM \& Perdagangan Jakarta Pusat dan staff CS and collection retribusi Jakarta Pusat, terdapat beberapa rekening pengusaha UKM yang gagal bayar (auto debet) tanggal jatuh tempo dan belum membayar 
ketika dilakukan penarikan retribusi secara tunai oleh pegawai Sudin UKM dan Perdagangan Pemkot masing-masing kota administrasi khususnya Pemerintah Kota Jakarta Pusat di tiap bulannya.

Tabel 1. Tingkat Pertumbuhan RetribusiLokasi SementaraTahun 2016

\begin{tabular}{ccccccc}
\hline Periode & \multicolumn{3}{c}{ Jumlah Pendapatan Retribusi } & \multicolumn{3}{c}{$\%$ Growth } \\
\cline { 2 - 7 } & $\begin{array}{c}\text { Jakarta } \\
\text { Selatan }\end{array}$ & Jakarta Pusat & Jakarta Timur & $\begin{array}{c}\text { Jakarta } \\
\text { Selatan (\%) }\end{array}$ & $\begin{array}{c}\text { Jakarta } \\
\text { Pusat (\%) }\end{array}$ & $\begin{array}{c}\text { Jakarta } \\
\text { Timur (\%) }\end{array}$ \\
\hline Januari & 15.436 .000 & 14.565 .000 & 0 & 0 & 0 & 0 \\
Februari & 150.834 .000 & 135.831 .000 & 385.250 .000 & 877 & 832 & 0 \\
Maret & 492.572 .000 & 394.572 .000 & 290.190 .000 & 227 & 226 & $-24,6$ \\
April & 430.392 .000 & 430.392 .000 & 122.460 .000 & -13 & 9,07 & $-88,8$ \\
Mei & 630.392 .000 & 430.392 .000 & 108.836 .000 & 46,4 & 0 & $-11,1$ \\
Juni & 552.446 .000 & 552.831 .000 & 181.230 .000 & $-12,3$ & 28,4 & 66,5 \\
Juli & 776.864 .000 & 756.609 .000 & 209.833 .000 & 40,6 & 36,9 & 15,78 \\
Agustus & 795.528 .000 & 792.537 .000 & 175.343 .000 & 2,40 & 4,74 & $-16,4$ \\
September & 1.125 .498 .000 & 1.023 .393 .000 & 246.098 .000 & 41,4 & 29,1 & 40,35 \\
Oktober & 1.261 .786 .000 & 1.259 .784 .000 & 112.428 .000 & 12,1 & 23,1 & $-54,3$ \\
November & 1.382 .382 .000 & 1.382 .382 .000 & 97.836 .000 & 9,55 & 9,73 & $-12,9$ \\
Desember & 1.425 .172 .000 & 1.525 .152 .000 & 131.090 .000 & 3,09 & 10,3 & 33,98 \\
\hline TOTAL & $\mathbf{8 . 9 4 1 . 3 0 2 . 0 0 0}$ & $\mathbf{7 . 4 3 8 . 6 5 6 . 0 0 0}$ & $\mathbf{2 . 0 6 0 . 5 9 4 . 0 0 0}$ & & & \\
\hline
\end{tabular}

Berdasarkan Peraturan Gubernur Provinsi Daerah Khusus Ibukota Jakarta Nomor 10 Tahun 2015 tentang Penataan dan Pemberdayaan Pedagang Kaki Lima, maka format aturan baku laporan kegiatan Dinas Koperasi UKM dan Perdagangan mulai dilaksanakan pada tahun 2016 hingga saat ini hanya mendapatkan data retribusi di tiap kota administrasi di tahun 2016 dan untuk tahun 2017, sedang dalam proses penyusunan untuk bahan publikasi website online portal masing-masing Pemerintah Kota.

Selain itu, untuk data pendapatan retribusi di tiap pemerintah kota yang diperoleh tidak sama. Hal ini karena Pemerintah Kota Jakarta Selatan dan Pemerintah Kota Jakarta Pusat melaksanakan regulasi gubernur tersebut dimulai pada bulan Februari 2016, sedangkan Pemerintah Kota Administrasi Jakarta Timur melaksanakan penyusunan laporan pendapatan retribusi pada bulan Maret 2016.

Berdasarkan data, dapat diketahui bahwa tingkat pertumbuhan pendapatan retribusi Lokasi Sementara terbaik selama tahun 2016 adalah Pemerintah Kota Jakarta Selatan. Pemerintah Kota Administrasi Jakarta Selatan berkinerja 102,85 \%, Pemerintah Kota Administrasi Jakarta Pusat sebesar 100,77\%, dan Pemerintah Kota Jakarta Timur sebesar $-4,29 \%$.

Berdasarkan data yang telah dianalisis seperti terlihat pada Tabel 2, dapat diketahui bahwa tingkat pertumbuhan pendapatan retribusi terbaik selama tahun 2016 adalah Pemerintah Kota Jakarta Selatan dengan rincian sebagai berikut Pemerintah Kota Administrasi Jakarta Selatan berkinerja 32,32\%, Pemerintah Kota Administrasi Jakarta Pusat sebesar 6,9\%, dan Pemerintah Kota Jakarta Timur sebesar 11,24 \%. 
Tabel 2.Tingkat Pertumbuhan Retribusi LokBin (Lokasi Binaan) Tahun 2016

\begin{tabular}{crrrrcc}
\hline \multirow{2}{*}{$\begin{array}{c}\text { Periode } \\
\text { (Bulan) }\end{array}$} & \multicolumn{3}{c}{ Jumlah Pendapatan Retribusi } & \multicolumn{3}{c}{$\%$ Growth } \\
\cline { 2 - 8 } & $\begin{array}{c}\text { Jakarta } \\
\text { Selatan }\end{array}$ & Jakarta Pusat & $\begin{array}{c}\text { Jakarta } \\
\text { Timur }\end{array}$ & $\begin{array}{c}\text { Jakarta } \\
\text { Selatan (\%) }\end{array}$ & $\begin{array}{c}\text { Jakarta } \\
\text { Pusat (\%) }\end{array}$ & $\begin{array}{c}\text { Jakarta } \\
\text { Timur (\%) }\end{array}$ \\
\hline Januari & 0 & 0 & 0 & 0 & 0 & 0 \\
Februari & 74.840 .000 & 0 & 58.968 .626 & 0 & 0 & 0 \\
Maret & 274.874 .000 & 301.148 .000 & 71.701 .650 & 267 & 0 & 21,59 \\
April & 462.560 .000 & 311.708 .000 & 156.663 .800 & 68,2 & 3,50 & 118 \\
Mei & 534.980 .000 & 311.708 .000 & 74.006 .532 & 15,6 & 0 & $-52,7$ \\
Juni & 580.795 .000 & 410.328 .000 & 81.675 .570 & 8,56 & 31,6 & 10,36 \\
Juli & 576.908 .000 & 433.312 .000 & 96.681 .412 & $-0,66$ & 5,60 & 18,37 \\
Agustus & 598.703 .000 & 480.004 .000 & 83.669 .324 & 3,77 & 10,77 & 13,45 \\
September & 624.481 .000 & 540.484 .000 & 91.150 .360 & 4,30 & 12,5 & 8,94 \\
Oktober & 653.944 .000 & 589.532 .000 & 91.756 .000 & 4,71 & 9,07 & 0,66 \\
November & 724.860 .000 & 647.188 .000 & 79.928 .000 & 10,8 & 9,77 & $-12,8$ \\
Desember & 765.894 .000 & 647.188 .000 & 87.164 .000 & 5,66 & 0 & 9,05 \\
\hline TOTAL & $\mathbf{5 . 8 7 2 . 8 3 9 . 0 0 0}$ & $\mathbf{4 . 6 7 2 . 6 0 0 . 0 0 0}$ & $\mathbf{9 7 3 . 3 6 5 . 2 7 4}$ & & & \\
\hline
\end{tabular}

\section{Analisis Share Pendapatan Retribusi UKM terhadap Pendapatan Retribusi Provinsi DKI Jakarta}

Dari hasil perhitungan share, diketahui bahwa masing-masing instansi pemerintah kota memiliki pengaruh yang besar terhadap total pendapatan retribusi Pemerintah Provinsi DKI Jakarta (Tabel 3). Hal ini dikarenakan dari Lokasi usaha Sementara menunjukkan bahwa Pemkot Jakarta Selatan memberikan sumbangan pendapatan retribusi yang paling besar terhadap total pendapatan retribusi Pemerintah Provinsi DKI Jakarta di tahun 2016 yaitu sebesar $29,25 \%$ dengan rincian nilai pengaruh kinerja lebih dari 1 atau bernilai (+) dengan masing-masing nilai sebagai berikut: Pemerintah Kota Administrasi Jakarta Selatan 29,249\%, Pemerintah Kota Administrasi Jakarta Pusat sebesar 24,33\%, dan Pemerintah Kota Jakarta Timur sebesar 6,74 \%.

Tabel 3. Analisis Share Pendapatan Retribusi UKM Provinsi DKI Jakarta terhadap Pendapatan Retribusi UKM Tahun 2016 (Lokasi Sementara dan Lokasi Binaan )

\begin{tabular}{cccccc}
\hline Nama Instansi & \multicolumn{2}{c}{ Pendapatan Retribusi } & $\begin{array}{c}\text { \% Share Retribusi Pemerintah Kota } \\
\text { terhadap Pemerintah Provinsi }\end{array}$ & Keterangan \\
\cline { 2 - 4 } & $\begin{array}{c}\text { Lokasi Sementara } \\
\text { (LokSem) }\end{array}$ & $\begin{array}{c}\text { Lokasi Binaan } \\
\text { (LokBin) }\end{array}$ & $\begin{array}{c}\text { Lokasi Sementara } \\
\text { (LokSem) }(\%)\end{array}$ & $\begin{array}{c}\text { Lokasi Binaan } \\
(\text { LokBin) }(\%)\end{array}$ & \\
\hline $\begin{array}{c}\text { Provinsi DKI } \\
\text { Jakarta }\end{array}$ & 30.568 .824 .000 & 16.650 .784 .274 & - & - & - \\
$\begin{array}{c}\text { Pemkot Jakarta } \\
\text { Selatan }\end{array}$ & 8.941 .302 .000 & 5.872 .839 .000 & 29,249 & 35,27 & $(+)$ \\
$\begin{array}{c}\text { Pemkot Jakarta } \\
\text { Pusat }\end{array}$ & 7.438 .656 .000 & 4.672 .600 .000 & 24,33 & 28,06 & $(+)$ \\
$\begin{array}{c}\text { Pemkot Jakarta } \\
\text { Timur }\end{array}$ & 2.060 .594 .000 & 973.365 .274 & 6,74 & 5,85 & $(+)$ \\
\hline
\end{tabular}

Sementara itu dari lokasi usaha binaan menunjukkan bahwa Pemkot Jakarta Selatan memberikan sumbangan pendapatan retribusi yang paling besar terhadap total pendapatan retribusi Pemerintah 
Provinsi DKI Jakarta di tahun 2016 yaitu sebesar 35,27\% dengan rincian nilai pengaruh kinerja lebih dari $1(+)$ dengan masing-masing nilai sebagai berikut Pemerintah Kota Administrasi Jakarta Selatan $35,27 \%$, Pemerintah Kota Administrasi Jakarta Pusat sebesar 28,06\%, dan Pemerintah Kota Jakarta Timur sebesar $5,85 \%$.

Berdasarkan hal tersebut, secara tidak langsung menunjukkan telah terjadi pertumbuhan ekonomi di Jakarta. Dengan kondisi perekonomian yang semakin bertumbuh, menunjukkan bahwa tingkat kemiskinan masyarakat mengalami penurunan, walau tidak signifikan. Menurut Siregar dan Wahyuniarti (2008), permasalahan kemiskinan tidak dapat dipecahkan hanya dengan meningkatkan pertumbuhan perekonomian semata dengan mengharapkan terjadinya efek menetes ke bawah (trickle down effect).

Tabel 4.Analisis Share Pendapatan Retribusi UKM Terhadap Pendapat Asli Daerah Pemprov DKI Jakarta di Tahun 2016

\begin{tabular}{|c|c|c|c|c|}
\hline Nama Instansi & $\begin{array}{l}\text { PAD Provinsi DKI } \\
\text { Jakarta (Rp) }\end{array}$ & $\begin{array}{l}\text { Pendapatan Retribusi } \\
\text { (LokSem + LokBin) }\end{array}$ & $\begin{array}{l}\text { \% Share Retribusi } \\
\text { Pemerintah Kota } \\
\text { terhadap PAD } \\
\text { Pemerintah Provinsi } \\
\text { DKI Jakarta (\%) }\end{array}$ & Keterangan \\
\hline $\begin{array}{l}\text { Pemkot Jakarta } \\
\text { Selatan }\end{array}$ & 62.184.392.259.364 & 14.814 .141 .000 & 0,023 & $(-)$ \\
\hline $\begin{array}{l}\text { Pemkot Jakarta } \\
\text { Pusat }\end{array}$ & & 12.111 .256 .000 & 0,019 & $(-)$ \\
\hline $\begin{array}{l}\text { Pemkot Jakarta } \\
\text { Timur }\end{array}$ & & 3.033.959.274 & 0,0048 & $(-)$ \\
\hline
\end{tabular}

Berdasarkan Tabel 4, diketahui bahwa total Pendapatan Asli Daerah (PAD) DKI Jakarta di tahun 2016 sebesar Rp. 62.184.392.259.364. Total pendapatan retribusi Lokasi Sementara dan Lokasi binaan Pemerintah Kota Administrasi Jakarta Selatan, Jakarta Pusat, dan Jakarta Timur tidak memiliki pengaruh yang besar terhadap total Pendapatan Asli Daerah (PAD) DKI Jakarta. Hal ini dikarenakan total pendapatan retribusi (Loksem dan Lokbin) Pemerintah Kota Administrasi Jakarta Selatan, Jakarta Pusat, dan Jakarta Timur tidak memiliki pengaruh yang besar terhadap total Pendapatan Asli Daerah (PAD) Provinsi DKI Jakarta di Tahun 2016. Hal ini dikarenakan nilai \% Share Retribusi Pemerintah Kota terhadap PAD Pemerintah Provinsi DKI Jakarta masing-masing bernilai kurang 1 (-) diantaranya Pemerintah Kota Administrasi Jakarta Selatan 0,023 \%, Pemerintah Kota Administrasi Jakarta Pusat sebesar 0,019 \%, dan Pemerintah Kota Jakarta Timur sebesar $0,0048 \%$.

Berbagai macam bentuk permasalahan dalam meningkatkan retribusi di masing-masing Kota Administrasi di DKI Jakarta, dapat diselesaikan dengan menggunakan strategi bagi Dinas UKM \& Perdagangan Pemerintah Kota Administrasi Jakarta Selatan, Jakarta Pusat, dan Jakarta Timur. Strategi ini antara lain adanya SOP Kinerja dan Laporan Pertanggung Jawaban Kinerja (LPJK) di tiap bulannya, kepemilikan SIM (Sistem Informasi Manajemen) terpadu bagi seluruh Sudin UKM \& Perdagangan di DKI Jakarta baik Loksem maupun Lokbin sebagai alat bantu rekapitulasi data Pedagang Kaki Lima bagi new database maupun maintenance/update existing database, melakukan analisa 5 C (Capital, Collateral, Character, Capacity, and Condition) dan 7 P (Personality, Party, Purpose, Prospect, Payment, Profitabillity, and Protection) dalam melakukan penilaian kriteria PKL yang menerima fasilitas Lokbin dan Loksem. Strategi lainnya adalah membuat kesepakatan bersama 
(MoU) Jangka Panjang antara Dinas UKM \& Perdagangan masing-masing PemKot dengan Bank DKI Jakarta mengenai data jumlah UKM LokSem maupun LokBin yang akan dan telah didebet rekening untuk pembayaran retribusi per tanggal 10 di tiap bulannya dengan tolak ukur pendataan laporan autodebet retribusi UKM khususnya Pedagang Kaki Lima, sehingga memiliki kesamaan antara data gagal dan berhasil debet di tiap bulannya.

Belanja pembangunan memberikan dampak yang positif dan signifikan terhadap PAD maupun pertumbuhan ekonomi (lihat Adi (2006), Ariani dan Utomo, (2017). Dengan demikian untuk meningkatkan Pendapatan Asli Daerah (PAD) hendaknya Pemprov DKI Jakarta meningkatkan pembelanjaan daerah terutama di sektor UMKM khususnya bagi pedagang kaki lima. Dengan semakin banyaknya pemerintah DKI Jakarta baik Pemerintahan Provinsi khususnya Pemerintahan Kabupaten/Kotamadya di DKI Jakarta melakukan pembelanjaan negara dalam bentuk pembangunan sarana prasarana kebutuhan masyarakat bagi seluruh warga DKI Jakarta khususnya para pelaku UMKM seperti Lokasi usaha, perlengkapan dan sarana pendukung berdagang bagi pedagang kaki lima, kemudahan akses informasi permodalan dan usaha, serta rasa aman dan nyaman dalam berdagang, dan sebagainya.

Jika fasilitas tersebut telah tersedia sepenuhnya, maka secara otomatis tingkat kesadaran (kewajiban) pembayaran retribusi dari para pelaku usaha baik di lokasi sementara maupun di lokasi binaan akan semakin meningkat. Hal ini berdasarkan Undang-Undang Nomor 28 Tahun 2009 tentang Pajak Daerah dan Retribusi Daerah, Retribusi jasa usaha yaitu pungutan atas pelayanan yang disediakan oleh pemerintah daerah dengan menganut prinsip komersial, yang meliputi pelayanan daerah dengan menggunakan/memanfaatkan kekayaan daerah yang belum dimanfaatkan, dan/atau pelayanan oleh pemerintah daerah sepanjang belum disediakan secara memadai oleh swasta. Termasuk dalam golongan retribusi ini yaitu retribusi jasa usaha pemakaian kekayaan daerah, retribusi pasar grosir/pertokoan, retribusi tempat pelelangan, retribusi terminal, retribusi tempat khusus parkir, retribusi tempat penginapan/pesanggrahan/vila, retribusi rumah potong hewan, retribusi pelayanan kepelabuhanan, retribusi tempat rekreasi dan olahraga, retribusi penyeberangan di air, serta retribusi penjualan produksi usaha daerah.

\section{SIMPULAN}

Berdasarkan uraian dalam bagian pembahasan dapat diambil kesimpulan bahwa posisi Pajak dan Retribusi Daerah sangat strategis bagi penyelenggaraan pemerintahan daerah (baik kabupaten/kota maupun provinsi) dan penerimaan Pedapatan Asli Daerah (PAD) khususnya sebagai indikator keberhasilan otonomi daerah dengan aspek kemampuan keuangan daerah untuk membiayai pelaksanaan urusan wajibnya. Berdasarkan kesimpulan sebagaimana telah diuraikan, maka dapat disampaikan saran-saran bahwa dalam upaya meningkatkan pendapat daerah dari sektor Pajak dan Retribusi Daerah, maka penyesuaian Perda tentang Pajak dan Retribusi Daerah harus memperhatikan tenggat waktu yang telah ditetapkan dalam Undang-Undang Nomor 28 Tahun 2009 agar dukungan keuangan dari hasil pemungutan Pajak dan Retribusi Daerah dapat dipenuhi.

\section{REFERENSI}

Adi, P.H. (2006). Hubungan Antara Pertumbuhan Ekonomi Daerah, Belanja Pembangunan dan Pendapatan Asli Daerah (Studi pada Kabupaten dan Kota se Jawa-Bali). Makalah Simposium Nasional Akuntansi 9 Padang. 
Ariani \& Mohamad Nur Utomo. (2017). Kajian Strategi Pengembangan Usaha Mikro Kecil Dan Menengah (UMKM) Di Kota Tarakan. Jurnal Organisasi dan Manajemen, Volume 13, Nomor 2, September 2017, 99-118.

De Kluvyer, Cornelis \& John A. Pearce II. (2006). Strategy A View from The Top. Pearson Prentice Hall, Second Edition.

Devita, A, Delis, A \& Junaidi J. (2014). Pengaruh Pendapatan Asli Daerah, Dana Alokasi Umum dan Jumlah Penduduk terhadap Belanja Daerah Kabupaten/Kota di Provinsi Jambi. Jurnal Perspektif Pembiayaan dan Pembangunan Daerah, Vol.2 No.2, Desember 2014.

Hakim, Lukman. (2012). Filosofi Kewenangan Organ Lembaga Daerah-Perspektif Teori Otonomi \& Desentralisasi Dalam Penyelenggaraan Pemerintah Negara Hukum dan Kesatuan. Malang. Setara Press.

Hamel, Gary \& C.K Praharald. (2011). Competing for the Future. USA : Harvard Bussiness School Press.

Lutfi, Achmad. (2006). Penyempurnaan Administrasi Pajak Daerah dan Retribusi Daerah: Suatu upaya dalam optimalisasi penerimaan PAD. Jurnal IImu Administrasi dan Organisasi: Bisnis \& Birokrasi, Volume XIV, Nomor 1, Januari 2006.

Mayasari, Luh Putu Rani, Ni Kadek Sinarwati, \& Gede Adi Yuniarta. (2014). Pengaruh Pertumbuhan Ekonomi, Pendapatan Asli Daerah dan Dana Alokasi Umum Terhadap Penglokasian Anggaran Belanja Modal Pada Pemerintah Kabupaten Buleleng. e-Journal S1 Ak Universitas Pendidikan Ganesha Jurusan Akuntansi , Volume: 2 No. 1 Tahun 2014.

Pemerintah Republik Indonesia. (1999). Undang-Undang No. 22 Tahun 1999 Tentang Pemerintahan Daerah. Bandung: Kuraiko Pratama.

Pemerintah Republik Indonesia. (1999). Undang-Undang No. 25 Tahun 1999 Tentang Perimbangan Keuangan Antara Pemerintah Pusat dan Daerah, Bandung: Kuraiko Pratama.

Pemerintah Republik Indonesia. (2000). Peraturan Pemerintah Republik Indonesia Nomor 104 tahun 2000Pengelolaan dan Pertanggungjawaban Keuangan Daerah.Departemen Arsip Negara Republik Indonesia. Jakarta.

Pemerintah Republik Indonesia. (2000). Peraturan Pemerintah Republik Indonesia Nomor 105 tahun 2000 Tentang Pengelolaan dan Pertanggungjawaban Keuangan Daerah.Departemen Arsip Negara Republik Indonesia. Jakarta.

Pemerintah Republik Indonesia. (2008). Undang-Undang Republik Indonesia Nomor 20 Tahun 2008 Tentang Usaha Mikro, Kecil, dan Menengah dan Undang-Undang Republik Indonesia. Departemen Arsip Negara Republik Indonesia. Jakarta.

Prasetyo, Tommy \& Dhyah Harjanti. (2013). Modal Sosial Pengusaha Mikro dan Kecil Sektor Informal Dan Hubungannya Dengan Kinerja Bisnis di Wilayah Jawa Timur.Jurnal AGORA Vol. 1, No. 3.

Tambunan, Tulus. (2009). Perkembangan Industri Skala Kecil di Indonesia. PT. Mutiara Sumber Widya, Jakarta.

Umar, Husein. (2005). Metode Penelitian Untuk Skripsi dan Tesis Bisnis. Jakarta: PT. Raja Grafindo Persada. 
Wenny, Cherrya D. (2012). Analisis Pengaruh Pendapatan Asli Daerah (PAD) Terhadap Kinerja Keuangan Pada Pemerintah Kabupaten dan Kota Di Propinsi Sumatera Selatan.Forum Bisnis dan Kewirausahaan, Vol 2 No. 1.hal 39-51.

Wirawati, N.G.P, Anggar Kusuma, Md. Krisna Arta. (2013). Analisis Pengaruh Penerimaan Pajak Daerah Dan Distribusi Daerah Terhadap Peningkatan PAD SeKabupaten/Kota di Bali. Bali: E-Jurnal AkuntansiUniversitas Udayana, 5.3 (2013):574-585. 